\title{
MEDDLING WITH THE MUDDLING RUSHDIE AFFAIR
}

\author{
DANA BĂDULESCU ${ }^{1}$ \\ Alexandru Ioan Cuza University of Iasi, Romania
}

\begin{abstract}
The "Rushdie affair" is one of the most far-reaching book events of the late $20^{\text {th }}$ century. This study argues that the Muslim demonstrations caused by the book's allegedly "blasphemous" nature, the fatwa and its aftermath may be regarded as a chain of snowballing effects which brought an entire century of book censorship to an end. However, what started the "affair" was not only The Satanic Verses that stirred waves of protests in the Muslim world and ambiguous attitudes in the West, but also its author, whose life was put in serious jeopardy by the fatwa. After 23 years since "the unfunny Valentine" was sent to Rushdie the "affair"'has not stopped radiating a whole spectrum of problems, which are still part of our global culture. This study traces the "affair" since the $14^{\text {th }}$ of February 1989, when the fatwa was decreed, until January 2012, when Sir Salman Rushdie was initially invited to give a video address to the Jaipur Literature Festival in India only to be announced that the address was cancelled on grounds of violence threats from Muslim activists.
\end{abstract}

Keywords: fatwa, The Satanic Verses, the "affair", Islam, the Qur'an, hybridity, freedom of expression, censorship

"If The Satanic Verses is anything, it is a migrant's-eye view of the world. It is written from the very experience of uprooting, disjuncture and metamorphosis (slow or rapid, painful or pleasurable) that is the migrant condition, and from which, I believe, can be derived a metaphor for all humanity."

Salman Rushdie, "In Good Faith"

${ }^{1}$ Dana Bădulescu, postdoctoral researcher, grantee of the Postdoctoral Programme Project "Applied social, human and political sciences. A programme of postdoctoral research training and scholarships in the field of human and political sciences"

ACKNOWLEDGEMENTS

This work was supported by the strategic grant POSDRU/89/1.5/S/62259, Project "Applied social, human and political sciences" co-financed by the European social fund within the Sectorial Operational Program Human Resources Development 2007 2013. e-mail address: dnbadulescu@yahoo.co.uk 


\section{Famous Infamous $20^{\text {th }}$ Century Books}

The very nature of the novel as a genre is that of offering its readers new perspectives, new ways in which they can look at the world afresh. While novelty can be enticing and challenging, it can also be regarded as potentially threatening and destabilizing.

Sir Salman Rushdie's novel The Satanic Verses stirred a large scale scandal and put its author's life in serious jeopardy for ten years on 14 February 1989. Thus, a whole century of allegedly "infamous" books was coming to a close. ${ }^{1}$ Launching The Satanic Verses into a world that had mercilessly banned and often burnt books written by "bastard children of history" like him, Rushdie stepped on more touchy toes than he ever thought he would. The Muslim "apostles of purity" (Rushdie 1991, 394) took offense, and maybe for the first time in recorded history a book started an international hurricane.

\section{Why Was The Satanic Verses Such a Bomb?}

The Satanic Verses was not Rushdie's first controversial book. In 1984, Indira Gandhi, the then Prime Minister of India, brought an action against Midnight's Children in the British courts, accusing a single sentence in chapter 28 of defaming her. The case was settled when Rushdie agreed to remove the offending sentence.

Rushdie's 1983 novel Shame focused on Pakistan, its political characters, its culture and its religion. Shame clearly references an episode of feud between Iskander Harappa, the fictional projection of Zulfikar Ali Bhutto ${ }^{2}$ and his successor and executioner Raza Hyder, modeled on the real life character of Zia ul-Haq. ${ }^{3}$ General Zia ul-Haq's military government banned Shame in Pakistan, a move which in fact attracted more attention to the book than the

${ }^{1}$ In 1915, D. H. Lawrence's novel The Rainbow was prosecuted in an obscenity trial, as a result of which all copies were seized and burnt; in 1928, Lawrence's Lady Chatterley's Lover was banned both in Britain and in America on moral grounds; in 1922, James Joyce's Ulysses was banned both in Britain and in America for being 'obscene'; in 1934, Henry Miller's Tropic of Cancer was banned in Britain and in America on moral grounds; in 1955, Vladimir Nabokov's Lolita was banned in Britain on moral grounds; in 1959, William S. Burrough's Naked Lunch was banned in Britain and in America on moral grounds; in 1957, Boris Pasternak's Doctor Zhivago was banned in the USSR on political grounds; in 1940, Graham Greene's The Power and the Glory was censored by Vatican on religious grounds.

2 Zulfikar Ali Bhutto was $9^{\text {th }}$ Prime Minister of Pakistan, and prior to that, $4^{\text {th }}$ President of Pakistan. He was executed in 1979.

${ }^{3}$ Together with his close officers, General Zia plotted a coup d'état in which Bhutto and members of his cabinet were arrested by troops of Military Police under Zia's order. 
government predicted it would. The actual consequence of the ban was that several Western capitals shipped copies to Islamabad, the capital of Pakistan, for their diplomats to read. The Western readers of the book sold their copies to used bookstores in the capital. Ironically, Rushdie's banned book found its way to used bookstores alongside stapled photocopied manuscripts of another censored book, Zulfiquar Ali Bhutto's If I Am Assassinated, which the former prime minister of Pakistan had written in his cell after Zia's coup. Censored books seem to have a remarkable resilience and a subversive solidarity, which made these two potentially destabilizing books fare clandestinely together in Islamabad, right under Zia's nose. It is also ironical that censorship and suppression are essential themes in Shame, while the fate of the book was to find its way around political censorship.

The news of Salman Rushdie being fatwaed by Ayatollah Ruhollah Khomeini for the alleged blasphemies in The Satanic Verses dominated the news and stirred violent emotions on a global level. Daniel Pipes argues that "censorship, protests, riots, a death edict, a break in diplomatic relations, even a confrontation of civilizations - it all had a fantastical quality which made the incident more appropriate to the world of magical realism found in Rushdie's novels than to the sober world of politics." (Pipes 15) However, to the author this whole affair looked like "a bad Rushdie novel."

The controversy triggered by The Satanic Verses began in India, where it was banned by Rajiv Gandhi's government nine days after its publication, moved to Great Britain, where the Indians working for the Saudi-financed Islamic Foundation of Leicester suggested that the book be banned in Britain, too, then traveled to the United States, South Africa, Pakistan, and Iran.

Thus, the novel written by an author fascinated with the central role of violence and fury in both Eastern and Western cultures unleashed forms of violence that had never been related to a book before. In his attempt to account for the riots, the deaths, the book-burnings, the fire bombings, and the impact the fatwa had on freedom of expression in a multicultural society, Daniel Pipes states that "Rushdie's novel contains by no means the most blasphemous thoughts expressed by a Muslim" (Pipes 1990, 16) before the date of its publication. Why then could not Rushdie get away with his alleged "offense" with impunity?

\section{Muslim Reactions to "What's in a Name"}

The second section of The Satanic Verses titled "Mahound" contains the subplot of the novel. "Mahound" or "Mahoun", a variant form of the name Muhammad, often found in medieval and later European literature, is strongly associated with anti-Muslim attitudes in Western Christendom. These variants of Muhammad's name are connected to the Christian belief that Muhammad was a 
god worshipped by Pagans, or even worse, that he was a demon who originated a false religion.

Apart from the connotations of the name "Mahound", section 2 of The Satanic Verses is set in "Jahilia", which references "Jahiliyyah", an Islamic concept of "ignorance of divine guidance" or "the state of ignorance from the guidance of God" or "Days of Ignorance," the age of pre-Islamic Arabia, prior to the revelation of the Our'an to Muhammad. In "Return to Jahilia" Rushdie imagines a brothel named Hijab - the Curtain. Muslims found Rushdie's calling a brothel by that name an insult. Moreover, in the brothel Rushdie places twelve prostitutes, who take on the names and the personalities of the Prophet's wives.

There are several aspects in the novel that raise doubts about the divine source of the Qur'an. A character in the book named Salman ${ }^{1}$, who serves as Mahound's scribe, starts making alterations in the text of the Book. Mahound does not notice the alterations for a while, but eventually Salman's deed is discovered. The episode ends ambiguously, casting doubt upon faith for "What is the opposite of faith? Not disbelief. Too final, certain, closed. Itself a kind of belief. Doubt." (Rushdie, The Satanic 92)

At the centre of the "Mahound" section in The Satanic Verses lies a disputed episode in the birth of Islam known as "the Satanic verses." This episode was discovered by young Rushdie while he was studying history at King's College, Cambridge. The legend has it that in the early days, Muhammad had problems converting people to the monotheism of Islam. According to the story, Muhammad was tricked by the devil into the compromise of allowing the people to worship their favourite pagan goddesses, too. However, when the Angel Gabriel revealed Satan's deed, the so-called "Satanic verses" were removed from the Qur'an.

Thinkers of Islam have argued that the Satanic verses were "fabricated." Therefore, they are deemed to be "a fable and a detestable lie." There is a large consensus in the Islamic world that the Satanic verses are apocryphal. It follows that anyone who dares to raise the issue is seen as a blasphemer whose sole intentions are to discredit Islam. To close the debate on this topic, it has been decided that there is hardly anyone - either Muslim or Westerner - who can have a competent and reliable opinion on this matter. Those few who may be familiar with it are a small number of specialists on early Islam.

Although Rushdie is not the first writer to question and challenge the divine nature of Islam, no writer before him had been so daring as to use the contentious nature of the Satanic verses as the bases for a novel bearing such a

${ }^{1}$ Apart from ringing the bell of Rushdie's own first name, Salman refers to one of Muhammad's closest companions and a major figure in Islamic history, Salman alFarisi ("Salman the Persian"). There are some fringe Islamic sects that claim Salman was actually angel Gabriel in disguise. 
title. The title has the effect of foregrounding a theme which for Rushdie was the expression of hybridity seen as "impurity, intermingling, the transformation that comes of new and unexpected combinations of human beings, cultures, ideas, politics, movies, songs." (Rushdie, Imaginary Homelands 394)

\section{Fatwa: Political Ploy or Act of Religious Piety?}

The fatwa made of the Ayatollah the great defender of Islam against the West in the eyes of many Muslims. Rushdie himself was vilified and called 'a devil' by the Muslim rioters in Bradford. Not only copies of The Satanic Verses were burned publicly but also dummies of its author.

Rushdie's British literary friends considered those public book and dummy burnings horrific symbolic events that reminded them of the Nazis. Apart from these Western supporters of Rushdie, there were also many Muslims who were against the fatwa, though few dared to speak out. Those who did argued that there was no support for the fatwa in the religion of Islam.

On the other hand, supporters of the ayatollah considered his act an essentially religious response to a religious offense. The Iranian chargé d'affaires in London stated that Khomeini saw the punishment of Rushdie as "much more important than relations between two countries." The top Iranian diplomat in Cyprus declared to a local audience that "the verdict issued by the Iranian leader is a purely religious one and based on religious considerations." (Pipes 96)

Pipes argues that while almost all the critics of the fatwa see it as a political act, its supporters regard it as a religious edict. Khomeini's timing of the edict logically supports the ayatollah's intentions to use it politically: indeed, had he meant the fatwa to punish Rushdie, he could have secretly dispatched a terrorist squad. Instead of taking immediate action, Khomeini broadcast the threat, giving Rushdie time to take cover. However, this hypothesis has its flaws when tested against Khomeini's method of dealing with offenders. Nasty offenders like Rushdie deserved public denunciation as well as death. By broadcasting the fatwa, Khomeini suggested that to kill Rushdie was the duty of any righteous Muslim, and so it transcended Iranian state interests.

The storms of protests of so many Muslims in Great Britain, South Africa, Pakistan and India, which took place before the fatwa was issued, are strong arguments in favour of the religious motivation of Khomeini's act. Before it was in the hands of public figures of politicians and religious leaders, the Rushdie affair was thrown at the world by ordinary Muslims.

In Britain, both ordinary Muslims and some Muslim intellectuals felt betrayed by Rushdie, whom they had hitherto considered "one of their own." However, what the Muslim reactions to The Satanic Verses signaled was a rift between those who accused Rushdie of debasing Islam and embracing Western 
forms of prejudice against it, on the one hand, and those who found Rushdie's use of "Mahound" and "Jahilia" in the novel a way in which the author actually debunked the use of these terms and so reversed their meanings. Outstanding Muslim writers in Iran, Algeria, Palestine and Lebanon wrote in defense of Rushdie in the volume For Rushdie. The mass protests and public book burnings in Bradford, India and Islamabad, on the other hand, were organized mainly by Muslim "non-readers" of the book.

Rushdie's opinion is that "the controversy over The Satanic Verses needs to be looked at as a political event, not purely a theological one." $\mathrm{He}$ argues that it was used politically in India "to demonstrate the strength of the Muslim vote." In South Africa, Pakistan, and Iran it also served a political purpose. Rushdie believes that in Britain, the "affair" helped the mosques to redress the balance of power back towards them although "many Muslims up and down the country find it embarrassing, even shameful, to be associated with such illiberalism and violence." (Rushdie, Imaginary Homelands 410)

\section{Rushdie's Response}

Iran did not ban the book straight away. The novel was even reviewed in an Iranian newspaper. However, noticing the protests in India and Britain, a delegation of mullahs from the wholly city of Qum read a section of the book to Khomeini, including the part featuring a mad imam in exile, which was an obvious caricature of Khomeini himself. Khomeini delivered the fatwa, calling the book a "calculated" attack by "colonialism" on the greatness and honour of the Muslim clergy. Thus, by delivering the fatwa as a response to all these alleged blasphemies of names, themes and portrayals, Iran won the competition of the greatest haters of Rushdie, and therefore of the West, with all its implications.

Four days after Rushdie received his "unfunny valentine", he issued an apology where he declared that he profoundly regretted the distress occasioned by the publication of the book to sincere followers of Islam. Iran's reaction to this apology changed from one day to the next: at first it was rejected, then accepted, and eventually Khomeini stated that even if Rushdie repented and "became the most pious man of all time" it was still the duty of every Muslim to "employ everything he has got" to kill him.

Rushdie's prime argument has always been the fictional nature of The Satanic Verses. The writer has reinforced this argument on various occasions when he was interviewed, and in his writings. The events, names and characters in The Satanic Verses do not claim to have the validity of historical events,

${ }^{1}$ This is a term used by Ruvani Ranasinha in his essay "The fatwa and its aftermath". The Cambridge Companion to Salman Rushdie. CUP, 2007 
names and characters because they happen in somebody's dream, where everything shifts and changes, nothing is as it really is in real life. In the essay "In Good Faith" from his collection of essays Imaginary Homelands, the writer explains that "fiction uses facts as a starting-place and then spirals away to explore its real concerns, which are only tangentially historical." (Rushdie 409)

Rushdie insists that he meant the novel to have the visionary not-of-thisworld quality of dreams. Thus, he writes:

See the 'offensive' chapters through this lens, and many things may seem clearer. The use of the so-called 'incident of the satanic verses', the quasihistorical tale of how Muhammad's revelation seemed briefly to flirt with the possibility of admitting three pagan and female deities into the pantheon, at the semi-divine, intercessory level of the archangels, and of how he then repudiated these verses as being satanically inspired - is, first of all, a key moment of doubt in dreams which persecute a dreamer by making vivid the doubts he loathes but can no longer escape. (Rushdie, Imaginary Homelands 399)

Since Freud's association of dream with literature, one may assume that readers make a pact with the author and with the text and accept this reading convention. As Rushdie accounts for "Jahilia", he argues that it "both "is and is not' Mecca." That is very possible in a novel, which "spirals away" from fact to fiction. The details of social life in that setting are drawn from historical research, but Jahilia "is also a dream of an Indian city." As to Muhammad's doubts and other allegedly belittling fallacies of the Prophet, Rushdie explains that they abound in Muslim tradition. By shedding light upon them, the author believes he actually made the character of Muhammad all the more interesting, "even more worthy of admiration." (Rushdie, Imaginary Homelands 409)

In the same essay, Rushdie argues that freedom "is taken, never given." Freedom of expression is just one form out of many, and "without the freedom to challenge, even to satirize all orthodoxies, including religious orthodoxies, it ceases to exist." (Rushdie, Imaginary Homelands 396)

According to Rushdie, freedom is a prerequisite of art, and art is among others - humankind's raison d'être. A novel is essentially a linguistic product of the imagination, and "language and imagination cannot be imprisoned, or art will die, and with it, a little of what makes us human." (Rushdie, Imaginary Homelands 396)

Rushdie implicitly distinguishes between fanatic orthodoxy and faith. In the light of this distinction, The Satanic Verses is not "always hostile to faith." (Rushdie, Imaginary Homelands 396) As to the shocking image in Gibreel's dream that whores in a brothel take the names of the Prophet's wives in order to arouse their customers, Rushdie explains that "throughout the novel, I sought images that crystallized the opposition between the sacred and the profane worlds. The harem and the brothel provide such an opposition." (Rushdie, 
Imaginary Homelands 401) The novelist's interest in the contrast between the sacred and the profane is not merely one focused on the opposition between the pure and the impure. Many theorists of the genre have seen the novel itself as essentially "messy" and impure. In Rushdie's hands, it becomes an expression of hybridity in its multitude of forms and a celebration of it. The novel is also a genre of a profane sensibility par excellence, which is emancipated from the religiousness of the sacred, and often manifestly challenging it.

Rushdie's crowning argument in his apology is that since he is "a secular, pluralist, eclectic man," he is not a Muslim, i.e. not a religious man. Thus, what holds for the novel as a genre also holds for Rushdie the novelist: as the novel is a secular genre, so is its author. Therefore, Rushdie will not accept the charge of apostasy or blasphemy because he has never affirmed any belief, "and what one has not affirmed one cannot be said to have apostasized from." The writer declares that having been described as an apostate Muslim makes him feel "concealed behind a false self." (Rushdie, Imaginary Homelands 405)

The statement that "books choose their authors" (Rushdie, Imaginary Homelands 408) metaphorically absolves Rushdie of all charges. The Satanic Verses chose Rushdie to write it, and what can a writer do but surrender to the call of inspiration and of his craft?

\section{Western Reactions}

Apart from Western reactions of support, there have been Western reactions of duplicity, or worse, reactions and declarations that made Rushdie responsible for the trouble in which he found himself after the $14^{\text {th }}$ of February 1989.

Daniel Pipes argues that the West censors any critical ideas about Islam. There have been Western critics of the backwardness of Islam who were sacked for their declarations or remarks, and who at the same time argued that similar criticism of Christianity would not have been sanctioned in the same way. What such consequences signal is that the West prefers to keep critical discussions of Islam taboo. If the taboo is broken, then the authors conceal their identity. Thus, a number of books on Islam have been published under pseudonym. In contrast, Muslims living in Europe are not prosecuted for blaming European civilization for all the evils of the modern world.

The censors are not always the Muslims who put pressure to prevent criticism of Islam or punish its authors, but there are cases when Western governments have attempted to thwart, or at least refused to support, criticism of Islam. The British government kept a low profile when the "affair" started. Although Rushdie's life was in extreme danger, he was not contacted by the government in any way, and though he was offered protection, the government 
saw him as a nuisance, an inconvenience on whom too much money was spent and who caused too much trouble. ${ }^{1}$

On several occasions, university authorities in Belgium cancelled permission for lectures and debates suspected of being critical of Islam. Sometimes there seems to be a resistance to such criticisms that does not need any bans issued - if a book or an article containing such criticisms is published it can be simply ignored by the scientific world and so it fails to enter public discourse.

Islamist organizations, having taken root and prospering in the West, have done their best to turn the laws of their host societies to their ideological advantage. Thus, political correctness has become a tool in their hands. Although things have changed since $9 / 11$, it is still risky to take liberties with the Islamic religion.

It is precisely this taboo that Rushdie has been attacking all the time.

\section{The Satanic Verses and "The Clash of Civilizations"}

Ruvani Ranashina argues that both Rushdie's novel and its controversial reception have become "a metaphor for 'the clash of civilizations'." The underlying principles of "dogmatic Islamic certainties" are pitted against those of "free enquiry of Western liberalism" (Ranashina 2007, 47) and its freedom of expression.

As the events around the book immediately after publication and in its long-term aftermath have shown, The Satanic Verses and the troublesome "affair" have shed light not only on the clash of civilizations, but also on the fissures within each civilization.

The opposition between the escalating violence and its strong rejection within the Muslim smaller or larger communities indicates that the Muslim world is not monolithic. Not all the Muslims are fanatics and fundamentalists. Some may be, as Rushdie himself is, "secular Muslims."

Perhaps one of the most significant problems of the Western civilization signaled by the "affair" is the crisis of multiculturalism, an essential aspect of our global world. As Charles Taylor argues, the principle of liberalism had to face the 'awkward' dilemma of how a 'tolerant society' deals with forms of

\footnotetext{
${ }^{1}$ Rushdie writes about an MP calling him on the very day of the fatwa to express his full support, only to retract the support after a few weeks. Likewise, the Guardian's columnist, Hugo Young, blamed Rushdie for the controversy, Lord Dacre imagined a violent scenario in which Rushdie was beaten up in a dark alley, and other champions of duplicity declared their support only to slip into cynical instigations to violence against the author of The Satanic Verses after a while. (Rushdie, 1991, 406)
} 
intolerance thrown at it by societies which do not share its principles. Taylor writes:

The awkwardness arises from the fact that there are substantial numbers of people who are citizens and also belong to the culture that calls into question our philosophical boundaries. The challenge is to deal with their sense of marginalization without compromising our basic political principles. (Taylor 1994, 63)

As many commentators have pointed out, the "affair" has signaled the persistence of a tension between religiousness and secularism in the West, although it seemed that this issue had been settled and left behind. All the corollaries of this tension have emerged to the surface in the wake of the fatwa. Questions like: "in terms of which philosophically underpinned attitude does one judge freedom and responsibility in writing, and is there any absolute?" have seriously thrown into a larger question the kind of world in which we live.

Debates around the "affair" have also proved that although Islam is not monolithic, it is largely kept in a state of inability to undergo renewal and change.

\section{Rushdie and India Today}

The ban on The Satanic Verses has been lifted in Libya, Turkey and Egypt, but it is still in force in India. In an interview after the cancellation of his video address to the Jaipur Literature Festival in January 2012, Rushdie wonders: "If Libya can do this, Turkey can do this, Egypt can do this, does India want to be a totalitarian state like China or does it want to move in the right direction towards liberty and the open discussion of ideas?"

What Rushdie finds worrying about the cultural development of India is the fact that ever since the Emergency, politicians across the spectrum in the country have been progressively moving from the secular principles on which the nation was founded towards religious groups that dictate policies.

The last minute cancellation of Rushdie's telecast participation in the Jaipur Festival was followed by a panel debate on freedom of expression where even the organizers stated that they felt they had been bullied, pushed against the wall, and left with no other option. For Rushdie, this cancellation goes beyond his personal relation with India and raises serious questions about the country's future. The writer reiterates the question he asked Rajiv Gandhi when The Satanic Verses was banned: "Would you like it to be a free country or would you like it to be one where you live in fear of religious violence?" 
That Rushdie was banished from the Jaipur festival ironically looks like an unmoving loop of time, which has made no progress since 1989. Rushdie calls it a "farce" and explains:

A writer of Indian origin, born in India, of Indian parents, holding the documentation that allows him to come and go from India as he chooses, wants to come to talk with other writers and readers at a meeting of writers and readers. It is very hard to see how that is offensive to anybody in India. /.../ It's a farce. It's farce, which has given a kind of tragic twist because of the introduction into it of the possibility of violence. I think the men of violence need to be called by their true name. These are violent men. This is gangsterism. That is the crime. The crime is to introduce violence into a peaceful situation and it didn't need to happen. So it's a black farce. I would say it's a black farce. (Full Transcript "I'm Returning to India, online)

The sad irony of it is that Salman Rushdie can be found on the Festival's list of attending speakers. After some twenty three years, the spectre of the fatwa and the divide it has stirred across East and West looms large over the author of The Satanic Verses. The farcical nature of this fatwa-related most recent episode lies in the space between Rushdie's (intended) presence / speech and (imposed) absence / silence, one which only Fiction can span. However, before fiction spans it, Rushdie's absence has generated debates which bring the "affair" into a new stage. The writer's silence at the Festival has certainly generated more words than the words of his address had he given it.

\section{Works Cited}

Abdullah, Anouar (ed.). For Rushdie: Essays by Arab and Muslim Writers in Defense of Free Speech. George Braziller, 1994.

Gurnah, Abdulrazak (ed.). The Cambridge Companion to Salman Rushdie. Cambridge: Cambridge University Press, 2007.

Gutmann, Amy (ed.). Multiculturalism: Examining the Politics of Recognition. Princeton: Princeton University Press, 1994.

Pipes, Daniel. The Rushdie Affair: the Novel the Ayatollah, and the West. New Brunswick: New Jersey Transaction Publishers, Fourth Printing, 2009.

Ranashina, Ruvani. "The fatwa and its aftermath." The Cambridge Companion to Salman Rushdie. Ed. Abdulrazak Gurnah, Cambridge: Cambridge University Press, 2007. 47.

Rushdie, Salman. The Satanic Verses. Viking, 1988.

Rushdie, Salman. Imaginary Homelands. Essays and Criticism 1981-1991. Penguin Books, 1991,

Taylor, Charles. "The Politics of Recognition." Multiculturalism: Examining the Politics of Recognition. Ed. Amy Gutmann, Princeton: Princeton University Press, 1994. 63. 
The Satanic Verses Affair, Salman Rushdie (Documentary) Iran, http://www.youtube.com/watch?feature=endscreen \&v=9-71XyNMzHY\&NR=1 Web. 15 January 2012

Christopher Mitchens on Salman Rushdie's fatwa, BBC, feb. 12, http://www.youtube.com/watch?v=P5Gcoi0J-DI Web. 10 January 2012

Full Transcript "I'm Returning to India, Deal with It", Salman Rushdie, NDTV, NDTV.com | Updated: January 25, 2012 00:53 IST, http://www.ndtv.com/article/india/full-transcript-im-returning-to-india-dealwith-it-salman-rushdie-to-ndtv-170122\&cp Web. 27 January 2012 